\title{
International Theory
}

\section{SUBMISSION OF ARTICLES}

International Theory invites authors to submit original theoretically oriented articles on the positive, legal, and/or normative aspects of world politics. Because IT is multidisciplinary with a broad intended audience, contributions must be as accessible as possible to readers from a wide range of disciplines and theoretical traditions. Papers that are primarily empirical or policy oriented are not a good fit.

We will not review manuscripts that have already been published, are scheduled for publication elsewhere, or have been simultaneously submitted to another journal; this applies to both print and online formats. All articles will be peer-reviewed by anonymous referees drawn for our Editorial Board and, on their advice, from relevant scholars around the world. Referees for the previous calendar year will be acknowledged in the final issue of each volume.

IT will review articles up to 15,000 words (including notes and bibliography), although authors will be encouraged to edit their papers to fewer than 12,000 words before publication. Brevity is encouraged and shorter papers will be advantaged in acceptance decisions. Please include a word count with submission, along with an abstract of no more than 150 words, which is not repeated from the paper itself.

References and citations should follow The Chicago Manual of Style. Citations in the text or footnotes should be limited to author's family name and date, with complete bibliographic information appearing in a list of references at the end of the article. The one exception is for legal articles; while strongly encouraged to follow the author-date system, if that proves unworkable legal authors may substitute the European Journal of International Law guidelines (available at http://www.ejil.org/ info/style-toc.html). All tables and figures must be cited in a paper. Figures ideally to be submitted as separate TIFF or EPS files. Full details can be found on our website at journals.cambridge.org

Titles of journals should not be abbreviated in the list of references (author-date system) or in the footnotes (legal articles). Table, figures and their accompanying legends should be placed at the end of the article with their desired location indicated in the text. Authors should submit their manuscript in electronic form as a MS Word file in an email attachment to it.mershon@ osu.edu. (Please do not submit the manuscript in PDF format). Authors should attach both a complete version of the manuscript as well as an anonymous version stripped of all identifying references to the author(s) that can be sent to reviewers.

To submit a manuscript, please visit www.editorialmanager.com/it, where you will find detailed information about the on-line submission procedure and required manuscript formatting.

Any questions about these procedures may be directed to the Editors.

\section{SUBSCRIPTIONS}

International Theory (ISSN 1752-9719) is published three time a year in March, July and November. Three parts form a volume.

The 2014 subscription price (excluding VAT) of a volume for institutional subscribers, which includes print and electronic access, is $£ 174.00$ (US $\$ 303.00$ in USA, Canada and Mexico). The electronic-only price available to institutional subscribers is $£ 145.00$ (US $\$ 272.00$ ). Single parts are $£ 63.43$ net (US $\$ 109.26$ in USA, Canada and Mexico) plus postage. The price for individuals certifying that the journal is for their personal use, which includes print and electronic access, is $£ 28.00$ (US $\$ 55.00$ ). EU subscribers (outside the UK) who are not registered for VAT should add VAT at their country's rate. VAT registered members should provide their VAT registration number. Japanese prices for institutions (including ASP delivery) are available from Kinokuniya Company Ltd, P.O. Box 55, Chitose, Tokyo 156, Japan.

Orders, which must be accompanied by payment, may be sent to a bookseller, subscription agent or direct to the publisher: Cambridge University Press, The Edinburgh Building, Shaftesbury Road, Cambridge CB2 8RU. Orders from the USA, Canada and Mexico should be sent to: Cambridge University Press, Journals Fulfillment Department, 100 Brook Hill Drive, West Nyack, NY 10994-2133, USA. Prices include delivery by air. Periodicals postage paid at New York, NY and at additional mailing offices.

\section{CoPYING}

This journal is registered with the Copyright Clearance Center, 222 Rosewood Drive, Danvers, MA 01923, USA. Organizations in the USA who are also registered with the C.C.C. may, therefore copy material (beyond the limits permitted by, sections 107 and 108 of U.S. Copyright law) subject to payment to the C.C.C of the per copy fee of $\$ 15.00$. This consent does not extend to multiple copying for promotional or commercial purposes. Code 1752-9719/14. Organizations authorized by the Copyright Licensing Agency may also copy, material subject to the usual conditions.

ISI Tear Sheet Service, 3501 Market Street, Philadelphia, PA 19104, USA, is authorized to supply single copies of separate articles for private use only.

For all other use, permission should be sought from Cambridge or from the American Branch of Cambridge University Press.

International Theory and all other Cambridge journals can be accessed at journals.cambridge.org

(C) Cambridge University Press 2014

ISSN 1752-9719

Printed by Bell \& Bain, Glasgow, UK. 
International Theory is open to theory of all varieties and disciplines, provided it addresses problems of politics and the international, broadly defined.

Published with the support of the Mershon Center, The Obio State University

Cambridge Journals Online

For further information about this journal please go to the journal web site at: journals.cambridge.org/it

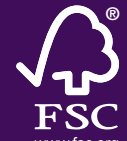

www.fsc.org
MIX

Paper from responsible sources FSC $^{\circledR}$ C007785

\section{CAMBRIDGE} UNIVERSITY PRESS 